\title{
Early Coital Debut and Associated HIV Risk Factors Among Young Women and Men in South Africa
}

\section{By Audrey Pettifor, Katie O'Brien, Catherine MacPhail, William C. Miller and Helen Rees}

Audrey Pettifor is assistant professor, Katie O'Brien is a graduate student and William C. Miller is associate professor-all at the Department of Epidemiology, School of Public Health, University of North Carolina, Chapel Hill, NC, USA. Catherine MacPhail is senior researcher, and Helen

Rees is professor and executive director, both at the Reproductive Health and

HIV Research Unit, University of the Witwatersrand, Johannesburg, South Africa.

CONTEXT: Young people in South Africa are at high risk of HIV infection. Because first sexual experiences may influence a young person's HIV risk, a better understanding of coital debut is needed.

METHODS: Data from a nationally representative survey that included 7,692 sexually active South African youth aged 15-24 were used to assess characteristics related to sexual debut and to respondents' first sexual partner. Poisson regression analyses were conducted to identify relationships among these characteristics and partner age differences, early coital debut (i.e., before age 15), forced sex with one's first partner and nonuse of condoms at first sex.

RESULTS: Eighteen percent of young men and 8\% of young women reported early coital debut. The likelihood of early debut was elevated among females and males who had had an older first partner (adjusted prevalence ratio, 1.1 per year) and among females who had had forced sex (2.5). Lack of condom use at first sex was associated with early coital debut (1.5) and forced sex (1.6) for males. Among females, the likelihood of nonuse was elevated for respondents who had had an early debut but had not had forced sex (1.3), and among those who had had both a later debut and forced sex (1.4).

CONCLUSIONS: Early coital debut is associated with factors that may increase a young person's risk for HIV infection, such as forced sex and having older partners. Intervention efforts should encourage youth to delay coital debut and promote strategies to make young people's first sexual experience safer.

International Perspectives on Sexual and Reproductive Health, 2009, 35(2):74-82.

The HIV epidemic in South Africa is severe. In 1991, only $1 \%$ of pregnant women attending antenatal clinics in the country were HIV-positive, but by 2006, the prevalence of HIV among pregnant women was 29\%. ${ }^{1}$ Among young people, females are at particularly high risk: In 2003, a nationally representative household survey of nearly 12,000 15-24-year-old South Africans found that 16\% of young women and $5 \%$ of young men were infected with HIV. ${ }^{2}$

Early coital debut may increase the risk of HIV infection. ${ }^{3-5}$ In places where the prevalence of HIV is high, such as South Africa, coital debut confers a substantial risk of sexual exposure to HIV. Furthermore, sexual behaviors at the time of early coital debut (e.g., nonuse of condoms) may set a precedent for future behaviors that elevate HIV risk. In addition, early debut is associated with increased risks of other STIs and pregnancy among young people. ${ }^{6-}$ 9

Although the prevalence of early sexual debut is often assumed to be particularly high in Sub-Saharan Africa, age at first sex is fairly consistent worldwide; for most young women in Africa, sexual debut occurs at ages $17-20 .{ }^{10}$ The mean age at first sex among young men and women in South Africa ranges from 16 to 18 years, depending on the age and type of sample. ${ }^{11-14}$

First sexual experiences are part of the transition to adulthood, and they are influenced by the environment, context and culture in which young people develop. ${ }^{15,16}$ Studies conducted among South African adolescents in the 1990s and early 2000s described gender norms that defined successful masculinity as having multiple sex partners, and that deemed using physical and sexual violence to establish control over female partners as acceptable behavior. ${ }^{17-22}$ Moreover, social norms dictated that intercourse and condom use be initiated by men; ${ }^{17,19,20,23}$ young women reported that they avoided discussing condom use for fear of violent reactions from their partners. ${ }^{17,19}$ This research clearly documents how inequities in gender power shape young women's first and subsequent sexual experiences and make many of these encounters risky.

Given the potential role of first sexual experiences in increasing the risk of HIV infection, improved understanding of the context of these events is needed to enhance behavioral intervention programs. In this article, we describe the first sexual experiences of a nationally representative sample of South African youth, and we examine the relationship between early coital debut and sexual behaviors occurring at first sex. Specifically, we examine, separately by gender and age-group, the associations between partner age differences and ever having been forced to have sex by one's first partner in relation to early coital debut, and between early coital debut and condom use at first sex. This is the first paper to describe South African youths' first sexual experiences using nationally representative data, and to use multivariable methods to explore the relationships among partner age, early debut and condom 
use at first sex among these youth .

\section{METHODS}

Sample

In 2003, the reproductive health and HIV research unit at the University of the Witwatersrand conducted a nationally representative household survey on HIV prevalence and sexual behavior among young people aged 15-24 in South Africa. Households were selected through stratified, disproportionate, systematic sampling in the country's nine provinces. One eligible young person per household was randomly selected to participate in a structured, faceto-face interview. Informed consent was obtained from all participants, and parental consent was obtained for those aged 15-17. Seventy-seven percent of eligible, enumerated young people completed the survey, yielding a sample of 11,904 youth. Our analyses of first sexual experiences were restricted to the 7,692 young people who reported ever having had sex.

Interview questions were translated from English into eight local languages and then back-translated to ensure accuracy. The study was approved by the University of the Witwatersrand human research ethics committee. Details on the survey's methods are described elsewhere. ${ }^{2}$

\section{Measures}

Participants provided information about their social and demographic characteristics, including age (categorized as 15-19 or 20-24), residence (rural or urban) and education (attending or completed high school vs. not attending or dropped out). In addition, detailed information on sexual behavior was collected from each young person. They were asked to report if they had ever had vaginal or anal sex, and the age at which each of these events had first occurred. The distinction between vaginal and anal intercourse was defined for participants in detail, so that there was no confusion as to what was meant by sexual intercourse. As per World Health Organization guidelines for adolescent HIV prevention programs, early sexual debut was defined as having had vaginal sex for the first time at age 14 or younger. ${ }^{24}$ For convenience, we refer to sexual debut after age 14 as a later debut.

Respondents were asked about the age of their first sexual partner (which we used to calculate age differences between the respondent and his or her partner), and whether the partner was a main partner (spouse, boyfriend or girlfriend), a regular casual partner (someone who was not a main partner, but with whom the respondent had had sex on an ongoing basis), a nonregular casual partner (someone who was not a main partner, and with whom the respondent had had sex only one or two times) or a sex worker. Respondents also reported the length of their relationship with their first partner and whether the relationship was ongoing; whether they had had sex with their first partner in the past 12 months, and if so, how often they had had sex with that partner in the past month; whether they had used a condom the first time they had had sex; whether they had used a condom the last time they had had sex with their first partner; whether they had always, sometimes or never used condoms with their first partner; whether they had ever had transactional sex with their first partner; whether their first partner had ever physically forced them to have sex; and whether they had ever used a contraceptive method with their first partner (and if so, what type). Finally, participants were asked to rate two aspects of their sexual debut: the degree to which they had wanted to have sex (really wanted, wanted, did not want or really did not want) and been willing to have sex (willing, persuaded, tricked, or forced or raped).*

\section{Analysis}

The data were weighted so that the sample was representative of 15-24-year-old respondents in the 2001 South African census. Analyses were conducted using Stata 10.0, and accounted for sample strata, primary sampling units and population weights.

We first present descriptive statistics of young people's first sexual experiences, stratified by age-group and gender. Chi-square comparisons were conducted to identify differences between young women's and young men's first sexual experiences; all comparisons were made within gender by age-group.

We then used simple and multivariable Poisson regression without an offset to examine the relationship between early coital debut and key sexual behaviors. These models provide an estimate of the prevalence ratio for the relevant outcome. ${ }^{25}$ All analyses were stratified by gender, regardless of the significance of any interactions.

Three models were created for each gender. The first model examined whether the difference in age between respondents and their first partners was associated with early sexual debut, and the second whether ever having been forced to have sex with one's first partner was associated with early sexual debut. The final model examined the relationship among those three measures and condom use at first sex. In each case, both unadjusted and adjusted models were developed. Variables that were hypothesized to confound the main relationship in each unadjusted model were entered into the multivariable models and retained on the basis of a manual backward elimination procedure (i.e., those that changed the effect estimate by at least 10\% were included). The main demographic variables (age, education and residence) and the sexual measures (early debut, partner age differences and forced sex) were kept in all of the adjusted models, even if they were not significantly associated with the outcome. In the

\footnotetext{
*Three questions were related to whether a respondent's first sexual experience was forced or voluntary. One question asked, “Did your first partner ever physically force you to have sex?"We used this question in our multivariate analysis, as research on rape in South Africa has found that women often do not report being raped when asked directly about it, but instead will report they have been "physically forced" to have sex (to our mind, they are the same thing). The other two questions concerned the wantedness of first sex and the degree to which the respondent was a willing participant (response options included "forced" and "raped"). We present descriptive results for these questions, but do not use them in the multivariate models.
} 
TABLE 1. Percentage distribution of males and females aged 15-24, by selected characteristics, according to age-group and gender, South Africa, 2003

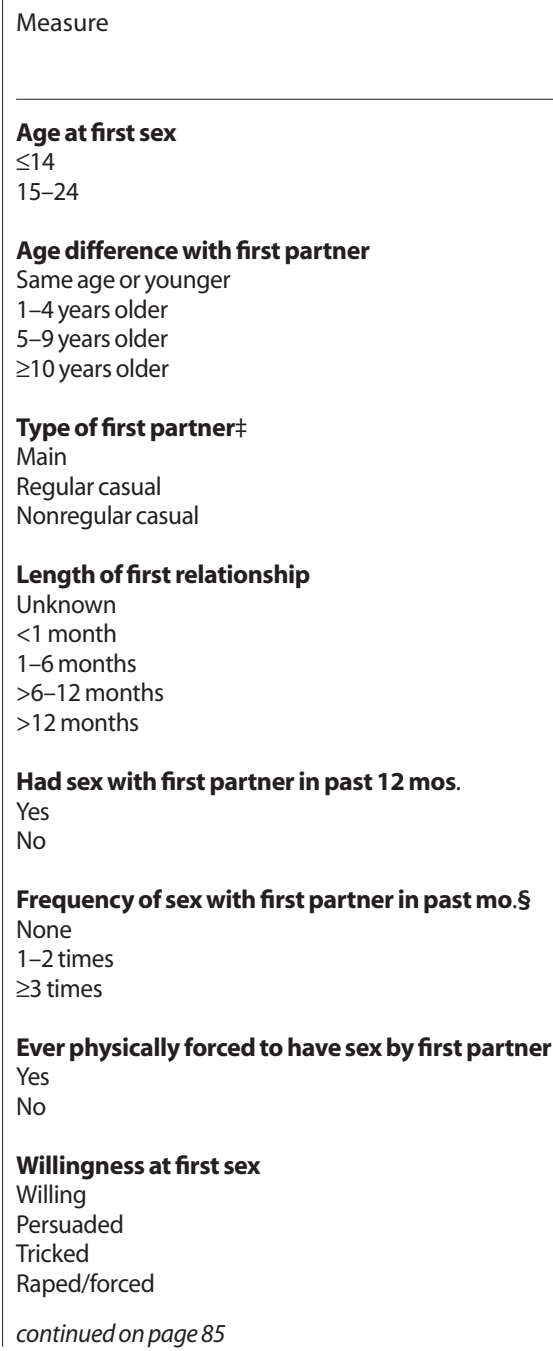

model for condom use at first sex, we examined potential interactions between forced first sex and early debut; interactions were considered significant at $\mathrm{p} \leq$. 1. In all three models, the age difference between partners was treated as a continuous rather than categorical variable, and the prevalence ratios for this measure refer to each additional year by which the partner is older than the respondent.

\section{RESULTS}

\section{Social and Demographic Characteristics}

Fifty-one percent of respondents were female, and the mean age of the sample was 19.1 years. Fifty-five percent of youth were living in urban areas; $73 \%$ reported living in a home with electricity. Nearly three-quarters (70\%) were still in school or had graduated from high school. Only $1 \%$ of males and 3\% of females were married. Eighty-two percent of respondents described themselves as black African,

*These are the racial categories predominantly used in South Africa; we acknowledge that they do not capture the country's racial and cultural diversity.
20-24

Females Males

$(\mathrm{N}=2,32$

4.0

$(\mathrm{N}=1,862)^{* * *}$

11.4

88.6

$(\mathrm{N}=2,321)$

$(\mathrm{N}=1,860)^{* * *}$

61.8

21.0

2.9

10.5

13

0.2

$(\mathrm{N}=1,757)^{* * * *}$

78.8

10.0

$(\mathrm{N}=1,760)^{* *}$

5.9

29.7

21.8

12.1

30.5

$(\mathrm{N}=1,756)^{* * *}$
42.1

42.1
57.9

$(\mathrm{N}=840)^{* *}$

65.4

20.3

14.3

$(\mathrm{N}=1,742)^{* * *}$

0.5

99.5

$(\mathrm{N}=1,751)^{* * *}$

97.2

2.4

0.2

0.1
$(\mathrm{N}=2,322)$
96.1

96.1

2.8

$(\mathrm{N}=2,325)$

$$
\begin{array}{r}
5.0 \\
7.7
\end{array}
$$

7.7

14.5

12.2

60.5

$(\mathrm{N}=2,323)$

$$
\begin{aligned}
& 40.5 \\
& 59.5
\end{aligned}
$$

( $\mathrm{N}=887)$

46.3

24.7

28.9

$(\mathrm{N}=2,310)$

$$
5.3
$$

94.7

$(\mathrm{N}=2,304)$

$$
\begin{array}{r}
60.7 \\
29.4 \\
6.5 \\
3.4
\end{array}
$$

$8 \%$ as colored, $7 \%$ as white and $2 \%$ as Indian. *

\section{First Sexual Experience and Partner}

- Sexual debut. Among 15-19-year-olds, 50\% of males and $47 \%$ of females reported ever having had sex. Among respondents aged $20-24,88 \%$ of males and $91 \%$ of females reported ever having had sex. The mean age at sexual debut was 16.4 years for males and 16.8 years for females. Overall, $18 \%$ of young men and $8 \%$ of young women said they had had sex for the first time at age 14 or younger. In both age-groups, young men were significantly more likely than young women to report having had early coital debut (Table 1).

- First partner characteristics. Most young men's first partners were the same age or younger, whereas young women's first partners were generally $1-4$ years older. Only 2-3\% of young women reported having a first partner who was 10 or more years older.

Most young women and men said that their first sexual partner was a main partner. Only $2 \%$ of young women and $1 \%$ of young men reported that these main partners were spouses; the remainder were boyfriends or girlfriends 
TABLE 1 continued.

Measure

\begin{tabular}{l|l}
$15-19$ & $20-24$
\end{tabular}

Wantedness of first sex

Really wanted

Wanted

Did not want

Really did not want

Used condom at first sex

Yes

No

Used condom at last sex with first partner

Yes

No

Consistency of condom use with first partner

Always

Sometimes

Never

Talked to first partner about condom use

Yes

No

Ever used contraceptive method with first partner

Yes

No

\begin{tabular}{r}
\hline Females \\
$(\mathrm{N}=1,716)$ \\
27. \\
40.4 \\
26. \\
6.0 \\
$(\mathrm{~N}=1,720)$ \\
53.4 \\
46. \\
\\
$(\mathrm{~N}=1,719)$ \\
51.9 \\
48. \\
\\
$(\mathrm{~N}=1,718)$ \\
35.0 \\
30.2 \\
34.8
\end{tabular}

$(\mathrm{N}=1,719)$
74
25

$(\mathrm{N}=1,720)$

42.9
57.1

Method used with first partner+†

Female/male condom

Pill/injectable

Other

55 .9

47.8

1.2

Totals

100.0

Males
$(\mathrm{N}=1,751)^{* * * *}$
83.2
15.2
1.1
0.5

Females Males

$(\mathrm{N}=2,303)$

31.5
41.9

21.9

4.6

$(\mathrm{N}=1,853)^{* * *}$

83.5

14.4

1.6

0.4

$\quad(\mathrm{N}=1,754)$

53.4
46.6

( $\mathrm{N}=2,309)$

41.4

$(\mathrm{N}=1,854) \dagger$

37.5

62.5

43.8
56.2

58.6

( $\mathrm{N}=1,855)$

$(\mathrm{N}=2,308)$

36.5

39.5

46.7

53.3

63.5

60.5

${ }^{*} \mathrm{p} \leq .05 .{ }^{* *} \mathrm{p} \leq .01 . * * * \mathrm{p} \leq .001 .+\mathrm{p}<.10 . \neq \mathrm{A}$ few respondents reported that their first partner had been a sex worker, but the proportion was statistically $0.0 \%$ for every gender-age combination. §Among those who had had sex in the past 12 months. ++ Among those who had used a method. Notes: $P$ values are for comparisons of distribution of responses between females and males, stratified by age-group. All N's are unweighted; percentages are weighted. Percentages may not total $100 \%$ be-

cause of rounding.

(not shown).

- First relationship. The length of respondents' first relationships differed by gender. Among 15-19-year-olds, 36\% of females and $31 \%$ of males reported that their relationship with their first sex partner had lasted more than a year; among 20-24-year-olds, the proportions were 61\% and $45 \%$, respectively. In the younger age-group, 34\% of males and $58 \%$ of females said that their relationship with their first sexual partner was ongoing ( $<<.01$; not shown); among 20-24-year-olds, the proportions were 24\% and $41 \%$, respectively $(\mathrm{p}<.01)$. Females were more likely than males to report that they had had sex with their first partner in the past year, among both 15-19-year-olds (66\% vs. $42 \%$ ) and $20-24$-year-olds (41\% vs. $27 \%$ ). Overall, $37 \%$ of young people who had an ongoing relationship with their first partner reported that they had not had sex with their partner in the past month (not shown).

- Coercion and wantedness of sex. Young women were far more likely than young men to report that their first partner had ever physically forced them to have sex. Seven percent of 15-19-year-old females and 5\% of 20-24-year-old females said that their first partner had ever forced them to have sex, compared with fewer than $1 \%$ of young men in those age-groups.

Most respondents said that they had been willing to have sex at the time of their sexual debut. In both agegroups, young men differed from young women in their willingness to have sex. Nearly all young men (96-97\%) said that they had been willing participants the first time they had sex, whereas only about three in five young women (57-61\%) said they had been willing. Moreover, wantedness of first sex differed between males and females; $83-84 \%$ of males and $27-32 \%$ of females reported that they "really wanted" their initial sexual encounter. Two percent of young women and $4 \%$ of young men reported having engaged in transactional sex with their first partner (not shown).

- Condom use. The proportion of respondents who said that they had used a condom the first time they had sex was similar among males and females, in both the younger age-group (44\% and 53\%, respectively) and the older agegroup (38\% and $41 \%$, respectively). The patterns of condom use at last sex with the first partner were similar to those at first sex. Consistent condom use was even more infrequent: Only 34-35\% of 15-19-year-olds and 21-25\% of 20-24-year-olds reported that they had always used a condom with their first partner. For all three condom use measures, levels differed between cohorts: Respondents in the younger age-group were more likely than 20-24-yearolds to report having used a condom the first time they 
TABLE 2. Unadjusted and adjusted prevalence ratios (and 95\% confidence intervals) from Poisson regression analysis examining the associations of having had an older first partner (Model 1) and having ever been forced to have sex by first partner (Model 2) with early coital debut, by gender

\begin{tabular}{|c|c|c|c|c|}
\hline \multirow[t]{2}{*}{ Measure } & \multicolumn{2}{|l|}{ Model 1} & \multicolumn{2}{|l|}{ Model 2} \\
\hline & Unadjusted & Adjusted & Unadjusted & Adjusted \\
\hline \multicolumn{5}{|l|}{ FEMALES } \\
\hline Older partner $\ddagger$ & $1.07(1.03-1.11)^{*}$ & $1.07(1.03-1.11)^{*}$ & na & na \\
\hline \multicolumn{5}{|l|}{ Forced sex } \\
\hline $\mathrm{No}(\mathrm{ref})$ & na & na & 1.00 & 1.00 \\
\hline Yes & na & na & $2.68(1.80-4.00)^{*}$ & $2.45(1.68-3.58)^{*}$ \\
\hline \multicolumn{5}{|l|}{ Age } \\
\hline $15-19$ & na & $3.76(2.69-5.25)^{*}$ & na & $2.45(1.68-3.58)^{*}$ \\
\hline 20-24 (ref) & na & 1.00 & na & 1.00 \\
\hline \multicolumn{5}{|l|}{ Education } \\
\hline \multicolumn{5}{|l|}{ Attending/completed } \\
\hline \multicolumn{5}{|l|}{ Not attending school/ } \\
\hline dropped out & na & $1.64(1.08-2.49)^{*}$ & na & $3.69(2.63-5.16)^{*}$ \\
\hline \multicolumn{5}{|l|}{ Residence } \\
\hline Urban (ref) & na & 1.00 & na & 1.00 \\
\hline Rural & na & $1.33(0.93,1.90)$ & na & $1.32(0.94,1.87)$ \\
\hline \multicolumn{5}{|l|}{ MALES } \\
\hline Older partner $\neq$ & $1.11(1.07-1.15)^{*}$ & $1.12(1.07-1.16)^{*}$ & na & na \\
\hline \multicolumn{5}{|l|}{ Forced sex } \\
\hline No (ref) & na & na & 1.00 & 1.00 \\
\hline Yes & na & na & $0.81(0.23-2.86)$ & $0.81(0.26-2.58)$ \\
\hline \multicolumn{5}{|l|}{ Age } \\
\hline $15-19$ & na & $1.94(1.58-2.38)^{*}$ & na & $1.97(1.61-2.41)^{*}$ \\
\hline $20-24$ (ref) & na & 1.00 & na & 1.00 \\
\hline \multicolumn{5}{|l|}{ Education } \\
\hline \multicolumn{5}{|l|}{ Attending/completed } \\
\hline \multicolumn{5}{|l|}{ Not attending school/ } \\
\hline dropped out & na & $0.68(0.50-0.91)^{*}$ & na & $0.64(0.48-0.87)^{*}$ \\
\hline \multicolumn{5}{|l|}{ Residence } \\
\hline Urban(ref) & na & 1.00 & na & 1.00 \\
\hline Rural & na & $1.52(0.83-2.76)$ & na & $1.38(0.76-2.50)$ \\
\hline
\end{tabular}

had sex, having used a condom the last time they had sex with their first partner and having always used a condom with their first partner (comparisons not shown; $\mathrm{p}<.001)$.

In both age-groups, females were more likely than males to report having talked to their first partner about using condoms. Females aged 15-19 were more likely to have talked to their first sexual partner about using condoms than their older counterparts ( $75 \%$ vs. $61 \%$; p $<.01$ ).

- Pregnancy prevention. In general, about half of males and females said that they had used a contraceptive method for pregnancy prevention (as opposed to HIV prevention) with their first sexual partner; the exception was 15-19year-old females, of whom $43 \%$ reported having used a method. However, males and females differed in the methods they reported having used. Among 15-19-year-olds, $84 \%$ of males had used a condom and $18 \%$ the pill or injectable; among females, $56 \%$ had used a condom and $48 \%$ the pill or injectable. In the older age group, most males $(71 \%)$ reported having used a condom, while most females (73\%) said they had used a hormonal method.

\section{Older Partners, Forced Sex and Early Coital Debut}

In multivariable models, age differences between partners were associated with early first sex among young women (Table 2, Model 1). For each additional year that a young woman's first partner was older than she was, the likelihood that she had had an early sexual debut increased significantly (adjusted prevalence ratio, 1.1). Forced sex was also associated with early debut (Model 2): Young women who reported that their first partner had ever forced them to have sex were more than twice as likely to have had sex before age 15 as those who had not been forced (2.5). Having an older first partner was also associated with an early sexual debut among young men (adjusted prevalence ratio, 1.1 per each additional year), but forced sex was not.

\section{Early Debut and Condom Use at Debut}

Among young women, the relationship between sexual debut and condom use at first sex was influenced by whether the respondent's first partner had ever forced her to have sex (Table 3). Compared with young women who had not been forced to have sex and had had later sexual debuts, those who both had been forced and had debuted later were significantly more likely to have not used a condom at first sex (adjusted prevalence ratio, 1.4), after adjustments for age, education and location. Similarly, women who had not been forced to have sex and had had an early debut were more likely not to have used a condom than those who had not been forced and had debuted later (1.3). However, the prevalence of condom nonuse at first sex did not differ between women who had experienced both forced sex and an early debut and those who had not been forced and had debuted later. For young men, the likelihood of not having used a condom at first sex was elevated among those who had been forced to have sex (1.6) and those who had had an early debut (1.5), but there was no interaction between the measures.

\section{DISCUSSION}

The majority of young people in this nationally representative sample did not report early coital debut or particularly high-risk first sexual encounters, contrary to what one might expect given the high prevalence of HIV infection among young people in South Africa. The mean ages at first sex for young men and young women were comparable with those from other studies of the same age-group in South Africa, ${ }^{11-13}$ and suggest that age at sexual debut has not changed significantly during the past decade.

\section{Older Partners}

In this study, respondents with an older first partner were more likely than their peers to have had first sex at an early age. However, partner age was not associated with condom use at first sex. Studies in the United States have documented an association between having an older first partner and being of young age at first sex, ${ }^{26,27}$ and we have reported that having an older partner is associated with an 
increased risk of HIV infection among young South African women. ${ }^{2}$ Although policymakers and researchers often emphasize that large age differences between partners can put the younger partner at risk for HIV, a woman's risk may be elevated even if the age difference is only a few years, particularly if her partner is in an age-group (e.g., 20-29) in which HIV prevalence is high. Furthermore, age differences need to be considered in relation to the age of the female partner: A five-year age difference may convey different risks for a 13-year-old than for a 20-year-old.

The vast majority of young women in our study reported that their first partner was only $1-4$ years older than themselves, and only about $1 \%$ reported having engaged in transactional sex with their first partner. Thus, the notion that most young women are "lured" into their first sexual experience by significantly older "sugar daddies" was not true in this population. A recent study among men in Kenya also found that the sugar daddy phenomenon is not as prevalent as anecdotal reports suggest. ${ }^{28}$

\section{Coerced and Forced Sex}

Young women who had had their sexual debut at an early age were more likely than other women to report that their first partner had ever physically forced them to have sex. This finding is consistent with results of studies conducted in other African countries and in the United States. ${ }^{29-}$ ${ }^{31}$ Young women were more likely than young men (5-7\% vs. $0-1 \%$ ) to report that their first partner had ever forced them to have sex. Given the sensitive nature of this issue, it is very likely that the true prevalence of forced sex is greater than that reported here. However, the proportions of women reporting forced sex in this study are similar to the lifetime prevalence of nonconsensual sex for women in other national South African studies. ${ }^{14,32}$ Although reports of forced sex were not extremely high, only about seven in 10 young women said that they had wanted to have sex the first time, and only six in 10 said that they had been willing participants. Similarly, Manzini and colleagues found that just 66\% of young women in Durban had engaged in their first sexual encounter willingly, while $20 \%$ reported having been persuaded, 10\% said they had been forced or raped, and 4\% had been tricked. ${ }^{12}$ Again, such reports of sexual coercion, violence and limited sexual decision making among young South African women are common in the literature. ${ }^{17-19,21-23,33}$

\section{Condom Use}

Young people who had had their sexual debut at an early age or whose first partner had ever forced them to have sex were more likely than other respondents to report not having used condoms at their first sexual experience. However, among young women, the association between early debut and condom use varied according to whether they had had forced sex. Specifically, compared with young women who had had a later debut and whose partner had not forced them to have sex, those who had had a later debut and had had forced sex, and those who had had an early debut but
TABLE 3. Unadjusted and adjusted prevalence ratios (and 95\% confidence intervals) from Poisson regression analysis examining the association of partner age difference, early sexual debut and forced sex with nonuse of condoms at coital debut, by gender

Measure

Unadjusted

Adjusted

FEMALES

Older partner $\neq$

$0.99(0.98-1.00)$

$1.00(0.99-1.00)$

Interaction between forced

sex and early debut

Not forced $x$ later debut (ref) 1.00

Forced x later debut $\quad 1.41$ (1.24-1.60)*

Not forced $x$ early debut $1.32(1.17-1.48)^{*}$

Forced $x$ early debut $\quad 1.06(0.70-1.61)$

Age-group

$15-19$

20-24 (ref)

na

na

Education

Attending/completed high

school (ref)

Not attending school/

dropped out

na

na

Residence

Urban (ref)

Rural

MALES

Older partner $\neq$

$0.98(0.96-0.99)^{*}$

Forced sex

No (ref)

Yes

Early debut

No (ref)

Yes

Age-group

15-19

20-24 (ref)

Education

Completed/attending high school (ref)

Not attending school/

dropped out

Residence

Urban (ref)

Rural

1.00

$1.44(1.08-1.93)^{*}$

1.00

$1.37(1.23-1.52)^{*}$

$1.29(1.16-1.44)^{*}$

$1.15(0.79-1.70)$

$0.79(0.71-0.87)^{*}$

1.00

1.00

$1.48(1.34-1.65)^{*}$

1.00

$1.40(1.26-1.55)^{*}$

$0.99(0.98-1.01)$

1.00

$1.56(1.16-2.09)^{*}$

1.00

$1.46(1.30-1.64)^{*}$

1.00

$1.47(1.36-1.59)^{*}$

na

na

$0.87(0.79-0.96)^{*}$

1.00

* $p \leq 05$. .Prevalence ratios are for each additional year in age difference between partners. Notes: ref=reference category. na=not applicable.

had not had forced sex, were more likely to not have used condoms the first time they had sex. Surprisingly, nonuse of condoms was no higher among young women who had had an early debut and had had forced sex than among those who had had a later debut and had not had forced sex. The lack of an association may be attributable in part to the small proportion of women ( $1 \%$ of sexually experienced females) who had had both an early debut and forced sex. Other studies have documented an association between early debut and lack of contraceptive (including condom) use at debut; ${ }^{15,34}$ associations have also been observed between forced and unwanted first sex and lack of contraceptive (including condom) use at first sex. ${ }^{29,30}$ 
For all measures of condom use, women in the younger age-group were more likely to report use than those aged 20-24. Our findings suggest that condom use may be increasing in South Africa (the prevalence of condom use at last sex among women aged 15-24 in the 1998 Demographic and Health Survey was only $17 \%{ }^{14}$ ); nevertheless, fewer than one-third of young people in this study reported consistent condom use with their first partner. Thus, a substantial proportion of young people had not been protected against HIV infection in their first sexual relationship. Previous work using this sample showed that the prevalence of condom use was lower among women with less gender power in their relationship and those whose partner had forced them to have sex than among those who had more power or who had not had forced sex. ${ }^{35}$ Thus, it is important that prevention programs continue to address gender norms that discourage youth from using condoms and to help develop supportive environments that facilitate condom use.

Talking to a partner about condom use is an important predictor of actual use, especially within a first sexual relationship. ${ }^{36,37}$ Qualitative research conducted with South African youth in the 1990s revealed minimal communication concerning condom use. ${ }^{17,20}$ Young women reported that they were afraid to mention condoms to their partners for fear of violent reactions. ${ }^{17,19}$ Interestingly, $75 \%$ of $15-$ 19-year-old women in our study reported that they had talked to their first sexual partner about condom use. This finding is encouraging and may be an indication that gender norms concerning condom communication have begun to change. Since 1999, a number of campaigns in South Africa have encouraged youth to talk about sex; the most notable of these is the loveLife HIV prevention campaign, whose tag line is "talk about it"-the "it" being sex and HIV prevention. Unfortunately, previous analyses of data from our survey found that young women who reported not having talked to their partner about condom use were significantly more likely than other women to be inconsistent condom users. ${ }^{36}$ Prevention programs must continue to provide young people with the skills they need to communicate effectively with their partner about safer sex, and must continue striving to change social norms about sexual communication.

Studies of South African adolescents have found that contraceptives are rarely used at sexual initiation. ${ }^{21}$ In this study, approximately half of young people reported that they had used a method of pregnancy prevention with their first partner; similarly, 44\% of young women in a previous study reported having used a contraceptive method the first time they had sex. ${ }^{12}$ Again, respondents aged 15-19 were more likely than those in the older age-group to report that they had used a condom as their method of pregnancy prevention. Reproductive health organizations in South Africa have worked to promote dual method use, and to reframe the male condom as a pregnancy prevention method and not solely a means of STI and HIV prevention. Given the high rates of HIV and pregnancy among young women, there is a tremendous need for prevention programs that emphasize the importance of dual protection.

Our study has several limitations. Recall error is likely for first sexual experiences, particularly for individuals whose sexual debut occurred long before their interview. In addition, as with all surveys of self-reported sensitive behavior, this survey likely suffers from underreporting and social desirability bias.

\section{Conclusion}

The majority of young people in this nationally representative sample did not report having had sex at an early age, and many said that they had used condoms, discussed condom use with their partner, been relatively close in age to their partner and engaged in sex willingly. However, because the prevalence of HIV infection in the general population is high, sexual behaviors that might be deemed low risk in low-prevalence settings (such as the United States) convey a much greater risk in South Africa. Given the risks associated with early debut, prevention campaigns should continue to encourage youth to delay the onset of first sex and aim to address contextual and structural factors that can help make this first experience safer for young people.

\section{REFERENCES}

1. South Africa Department of Health, National HIV and Syphilis Prevalence Survey, South Africa, 2006, Pretoria, South Africa: South Africa Department of Health, 2007.

2. Pettifor AE et al., Young people's sexual health in South Africa: HIV prevalence and sexual behaviors from a nationally representative household survey, AIDS, 2005, 19(14):1525-1534.

3. Pettifor AE et al., Early age of first sex: a risk factor for HIV infection among women in Zimbabwe, AIDS, 2004, 18(10):1435-1442.

4. Asiimwe-Okiror $\mathrm{G}$ et al., Change in sexual behaviour and decline in HIV infection among young pregnant women in urban Uganda, AIDS, 1997, 11(14):1757-1763

5. Laga M et al., To stem HIV in Africa, prevent transmission to young women, AIDS, 2001, 15(7):931-934

6. Greenberg J, Magder L and Aral S, Age at first coitus: a marker for risky sexual behavior in women, Sexually Transmitted Diseases, 1992 19(6):331-334.

7. Duncan ME et al., First coitus before menarche and risk of sexually transmitted disease, Lancet, 1990, 335(8685):338-340.

8. Coker AL et al., Correlates and consequences of early initiation of sexual intercourse, Journal of School Health, 1994, 64(9):372-377.

9. Kaestle CE et al., Young age at first sexual intercourse and sexually transmitted infections in adolescents and young adults, American Journal of Epidemiology, 2005, 161(8):774-780.

10. Wellings K et al., Sexual behaviour in context: a global perspective, Lancet, 2006, 368(9548):1706-1728.

11. Simbayi LC, Chauveau J and Shisana O, Behavioural responses of South African youth to the HIV/AIDS epidemic: a nationwide survey, AIDS Care, 2004, 16(5):605-618

12. Manzini N, Sexual initiation and childbearing among adolescent girls in KwaZulu Natal, South Africa, Reproductive Health Matters, 2001, 9(17):44-52.

13. Richter L, A survey of reproductive health issues among urban black youth in South Africa: final grant report to the Society for 
Family Health, Pretoria, South Africa: Centre for Epidemiological Research in South Africa, Medical Research Council, 1996.

14. South Africa Department of Health, Medical Research Council and Macro International, South Africa Demographic and Health Survey, 1998, Pretoria, South Africa: South Africa Department of Health, 2001.

15. Stone $\mathrm{N}$ and Ingham R, Factors affecting British teenagers' contraceptive use at first intercourse: the importance of partner communication, Perspectives on Sexual and Reproductive Health, 2002, 34(4):191-197.

16. Rosenthal SL et al., Sexual initiation: predictors and developmental trends, Sexually Transmitted Diseases, 2001, 28(9):527-532.

17. Varga CA, Sexual decision-making and negotiation in the midst of AIDS: youth in KwaZulu-Natal, South Africa, Health Transition Review, 1997, 7(Suppl. 3):45-67.

18. Wood K and Jewkes R, "Dangerous" love: reflections on violence among Xhosa township youth, in: Morrell R, ed., Changing Men in Southern Africa, Pietermaritzburg, South Africa: University of Natal Press, 2001, pp. 317-336.

19. MacPhail C and Campbell C, 'I think condoms are good but, aai, I hate those things': condom use among adolescents and young people in a Southern African township, Social Science \& Medicine, 2001, 52(11):1613-1627.

20. Harrison A, Xaba N and Kunene P, Understanding safe sex: gender narratives of HIV and pregnancy prevention by rural South African school-going youth, Reproductive Health Matters, 2001, 9(17):63-71.

21. Jewkes R et al., Relationship dynamics and teenage pregnancy in South Africa, Social Science \& Medicine, 2001, 52(5):733-744.

22. Maharaj P and Munthree C, Coerced first sexual intercourse and selected reproductive health outcomes among young women in KwaZulu-Natal, South Africa, Journal of Biosocial Science, 2007, 39(2):231-244

23. Wood K, Maforah F and Jewkes R, "He forced me to love him": putting violence on adolescent sexual health agendas, Social Science \& Medicine, 1998, 47(2):233-242

24. World Health Organization (WHO), National AIDS Programmes: A Guide to Indicators for Monitoring and Evaluating National HIV/AIDS Prevention Programmes for Young People, Geneva: WHO, 2004.

25. McNutt LA et al., Estimating the relative risk in cohort studies and clinical trials of common outcomes, American Journal of Epidemiology, 2003, 157(10):940-943.

26. Miller KS, Clark LF and Moore JS, Sexual initiation with older male partners and subsequent HIV risk behavior among female adolescents, Family Planning Perspectives, 1997, 29(5):212-214.

27. Ford K, Sohn W and Lepkowski J, Characteristics of adolescents' sexual partners and their association with use of condoms and other contraceptive methods, Family Planning Perspectives, 2001, 33(3): 100-105 \& 132

28. Luke N, Confronting the 'sugar daddy' stereotype: age and economic asymmetries and risky sexual behavior in urban Kenya, International Family Planning Perspectives, 2005, 31(1):6-14.

29. Abma J, Driscoll A and Moore K, Young women's degree of control over first intercourse: an exploratory analysis, Family Planning Perspectives, 1998, 30(1):12-18.

30. Koenig MA et al., Coerced first intercourse and reproductive health among adolescent women in Rakai, Uganda, International Family Planning Perspectives, 2004, 30(4):156-163.

31. Mathews $C$ et al., Predictors of early first sexual intercourse among adolescents in Cape Town, South Africa, Health Education Research, 2009, 24(1):1-10.

32. Jewkes R at al., "He Must Give Me Money, He Mustn't Beat Me": Violence Against Women in Three South African Provinces, Pretoria, South Africa: Medical Research Council, 1999.
33. Varga C, How gender roles influence sexual and reproductive health among South African adolescents, Studies in Family Planning, 2003, 34(3): 160-172

34. Manning WD, Longmore MA and Giordano PC, The relationship context of contraceptive use at first intercourse, Family Planning Perspectives, 2000, 32(3):104-110.

35. Pettifor AE et al., Sexual power and HIV risk, South Africa, Emerging Infectious Diseases, 2004, 10(11):1996-2004.

36. Blanc AK and Wolff B, Gender and decision-making over condom use in two districts in Uganda, African Journal of Reproductive Health, 2001, 5(3):15-28

37. Manlove J, Ryan S and Franzetta K, Patterns of contraceptive use within teenagers' first sexual relationships, Perspectives on Sexual and Reproductive Health, 2003, 35(6):246-255.

\section{RESUMEN}

Contexto: La gente joven en Sudáfrica está en alto riesgo de infección por VIH. Es necesaria una mejor comprensión del debut coital debido a que las primeras experiencias sexuales pueden influir en el riesgo de una persona joven de contraer el VIH.

Métodos: Los datos de una encuesta representativa a nivel nacional que incluyó a 7,692 jóvenes sudafricanos sexualmente activos de 15-24 años de edad, se utilizaron para evaluar las características relacionadas con el debut sexual y con la primera pareja sexual de las personas entrevistadas. Se condujo una serie de análisis de regresión de Poisson para identificar las relaciones entre esas características y las diferencias de edad de las parejas, el debut coital temprano (i.e., antes de los 15 años), el sexo forzado con la primera pareja y la falta de uso del condón en la primera relación sexual.

Resultados: El 18\% de los hombres jóvenes y el 8\% de las mujeres jóvenes reportaron un debut coital temprano. Tanto en las mujeres como en los hombres, el debut temprano se asoció con el hecho de tener una pareja mayor (razón de prevalencia ajustada, 1.1 para cada año) y con las relaciones sexuales forzadas en las mujeres (2.5). Entre los hombres, la falta de uso del condón en la primera relación sexual se asoció con el debut coital temprano (1.5) y con las relaciones sexuales forzadas (1.6). Entre las mujeres, la probabilidad de no usar condón fue elevada en las personas entrevistadas que habían tenido un debut temprano pero que no habian tenido relaciones sexuales forzadas (1.3); y entre quienes tuvieron tanto un debut tardio como relaciones sexuales forzadas (1.4).

Conclusiones: El debut coital temprano está asociado con factores que pueden aumentar el riesgo de una persona joven de contraer el VIH, como las relaciones sexuales forzadas y el tener parejas de mayor edad. Los esfuerzos de intervención deben alentar a las y los jóvenes a retrasar su debut coital y a promover estrategias que hagan más segura la primera experiencia sexual de la gente joven.

\section{RÉSUMÉ}

Contexte: Les jeunes d'Afrique du Sud courent un risque élevé de contraction du VIH. Étant donné que les premières expériences sexuelles peuvent influencer le risque d'infection des jeunes, il importe de mieux comprendre les circonstances de l'initiation sexuelle. 
Méthodes: Les données d'une enquête nationalement représentative auprès de 7.692 jeunes hommes et femmes de 15 à 24 ans sexuellement actifs en Afrique du Sud ont servi à évaluer les circonstances et caractéristiques des premiers rapports sexuels et du premier partenaire sexuel des répondants. Des analyses de régression de Poisson ont été menées pour identifier les rapports entre ces caractéristiques et les différences d'âge des partenaires, l'initiation sexuelle précoce (avant l'âge de 15 ans), les rapports sexuels forcés avec le premier partenaire et l'omission du préservatif lors des premiers rapports sexuels. Résultats: Dix-huit pour cent des jeunes hommes et $8 \%$ des jeunes femmes ont fait état d'une initiation sexuelle précoce. L'initiation précoce est apparue associée au fait d'avoir un ou une partenaire plus âgé/ / pour les jeunes femmes comme pour les jeunes hommes (rapport de prévalence ajusté de 1,1 par année) et aux rapports forcés pour les jeunes femmes $(2,5)$. L'omission du préservatif lors des premiers rapports sexuels est associée à l'initiation sexuelle précoce $(1,5)$ et aux rapports forcés $(1,6)$ chez les jeunes hommes. Côté féminin, la probabilité d'omission est élevée parmi les répondantes qui avaient connu une initiation sexuelle précoce mais sans rapports forcés $(1,3)$ et parmi celles qui avaient à la fois connu une initiation plus tardive et des rapports forcés $(1,4)$

Conclusions: L'initiation sexuelle précoce est associée à des facteurs susceptibles d'accroître le risque pour une jeune personne de contracter le VIH, comme les rapports sexuels forcés et le fait d'avoir des partenaires plus âgés. Les efforts d'intervention doivent encourager les jeunes à différer leur initiation sexuelle et promouvoir les stratégies aptes à réduire le risque de la première expérience sexuelle.

\section{Acknowledgments}

The authors thank Development Research Africa for conducting the field work for the national survey, and the University of the Witwatersrand's Central Laboratory Services for conducting all laboratory testing associated with the survey.

Author contact: apettif@email.unc.edu

\section{OTHER GUTTMACHER INSTITUTE RESOURCES ON ADOLESCENT REPRODUCTIVE HEALTH IN DEVELOPING COUNTRIES}

\section{Country-Specific Reports}

Adolescent Marriage and Childbearing in India: Current Situation and Recent Trends

By Ann M. Moore, Susheela Singh, Usha Ram, Lisa Remez and Suzette Audam

\section{Meeting Young Women's Sexual and Reproductive Health Needs in Nigeria}

By Gilda Sedgh, Akinrinola Bankole, Friday Okonofua, Collins Imarhiagbe, Rubina Hussain, Deirdre Wulf

\section{Regional Overviews}

Ensuring a Healthier Tomorrow in Central America: Protecting the Sexual and Reproductive Health of Today's Youth

By Lisa Remez, Elena Prada, Susheela Singh, Luis Rosero Bixby and Akinrinola Bankole

Protecting the Next Generation in Sub-Saharan Africa: Learning from Adolescents to Prevent HIV and

Unintended Pregnancy

By Ann E. Biddlecom, Laura Hessburg, Susheela Singh, Akinrinola Bankole and Leila Darabi

\section{In-Depth Policy Analyses}

A Long and Winding Road: Getting the HPV Vaccine to Women in the Developing World

By Susan A. Cohen

\section{Young People Need Help in Preventing Pregnancy and HIV; How Will the World Respond?} By Heather D. Boonstra

These and other resources on adolescent sexual and reproductive health are available on the Guttmacher Institute Web site at <http://www.guttmacher.org/sections/adolescents.php >. 